\title{
On the emergence of verb paradigms in one Spanish child
}

\author{
Carmen Aguirre \\ Wien \\ Carmen.aguirre@univie.ac.at
}

\section{Introduction}

This paper studies the acquisition process of Spanish verbal morphology in a monolingual child. The study focuses on the period of the first 50 verb lemmas. This covers the period from age $1 ; 7$ till $1 ; 10$.

The data shows that the verb acquisition process of this Spanish child follows three main stages:

1. A lexical stage in which verbs are only acquired as a lexical element.

2. A syntactic stage in which the verb, still contemplated as a non-split word, becomes the main element in the development of thematic and semantic relations.

3. A morphological stage in which verb suffixes begin to be analysed separately. At this stage, the relationship between form and meaning starts and the functional categories linked to the verb (tense, aspect, agreement, mood...) begin to be acquired. Just at this moment, the first miniparadigms appear, which suggests that the acquisition process of verb morphology has started.

The first two stages are premorphological and cover in our child the period till 1;9. In the last stage, which begins at $1 ; 10$, the child enters the protomorphological stage.

\section{System-defining properties of Spanish verb morphology}

\subsection{Productive categories}

Non-finite forms: infinitive, gerund and perfect participle.

Finite forms represent five verbal categories: tense, mood, aspect, person and number.

Tense: present, past and future.

Mood: indicative, subjunctive, conditional and imperative.

Aspect: perfect and imperfect.

Person: $1^{\text {st }}, 2^{\text {nd }}$ and $3^{\text {rd }}$.

Number: singular and plural, for each person.

Indicative mood patterns with four simple tense categories: one present, one future and two past tenses: perfect (pretérito indefinido) and imperfect (pretérito imperfecto). Subjunctive has one tense category for the present, one for the past and one for the future (unproductive). Imperative has two forms: one for the second person of singular and one for the second person of plural. This means a total amount of 59 simple forms (115 if we add the analytic ones, the perfective couples) that the child has to learn in his acquisition process.

All these synthetic forms are imperfective (only the simple past perfect is not) and each of these paradigms has an analytical counterpart (aux + participle), which is normally perfective.

Tense category combinations have normally a single form, but one of them, the past imperfect of subjunctive has two allomorphs (cantara-cantase). 
There are two further, very much used, grammatical periphrasis: the continuous present (estoy comiendo 'I am eating') and the periphrastic future, much more employed than the synthetic one, voy a comer 'I am going to eat').

\subsection{Base and Spanish verbal suffixes}

The base is a stem, integrated by the root plus a thematic vowel (a, e, i): cantar, temer, partir. There are some cases of substitution (1 p.s. pres. ind -canto; pres subj-cante; 1-3 p. s. pret. ind.-canté)

Marker types are mostly suffixes plus a few thematic vowel substitutions. Also, zero forms occur in some unmarked categories.

As a consequence, every verbal form consists of:

$$
[\text { ROOT + THEMATIC VOWEL }]+\text { SUFFIX }_{1}+\text { SUFFIX }_{2}
$$

The first suffix ( suff $_{1}$ ) informs about tense (the present is the unmarked category) mood and aspect. The second suffix ( suff $_{2}$ ) is the agreement suffix and refers to person and number. Changes in the thematic vowel have also a morphosemantic value.

\subsection{Verb Macroclasses}

2 macroclasses, signalled by the thematic vowel ( $a$ vs. $e / i)$

$$
1^{\text {st }} \text { cantar a 'to sing' } \quad 2^{\text {nd }} \text { temer e to be afraid / partir } \mathbf{i}^{\prime} \text { to leave' }
$$

The first macroclass (class - ar verbs) is the biggest one (more than $90 \%$ of verbs) and the only productive class.

The thematic vowel (TV) defines the 2 macroclasses, and the 2 classes inside the second macroclass.

The two macroclasses of verbs are very stable, none of them loses members.

So, we can conclude that the ar macroclass is the dominant one while the er/ ir macroclass is unproductive but stable.

\subsection{High degree of congruity and high degree of iconicity ${ }^{1}$}

The degree of congruity of the different classes is very high: the er/ ir macroclass does not differ much in their defining structural properties from the dominant macroclass ar

The agreement markers of person and number (NP) are superstable markers, because they hold throughout the conjugation ${ }^{2}$, only the $2^{\text {nd }} \mathrm{sg}$. marker is different in the preterito indefinido of indicative (vulgar varieties and children speech add one $s$ at the end and superficially regularise the paradigm-comistes instead of comiste).

Most of the tense aspect and mood (TAM) markers are superstable markers. We find only a few distinctive markers for the two macroclasses:

Imperfecto de indicativo. ba vs. a (cantaba/comía)

I p.s. pretérito indefinido. é vs. í (canté / comí)

3 p.s. pretérito indefinido ó vs. ió (cantó / comió)

1 This morphological characterization is based on Natural Morphology (Dressler et al. 1987; Kilani-Schoch 1988)

2 There is a case of automatic fusion in the second person plural $(i+i s>i s)$ partís. 
Presente de subjuntivo. $e$ vs. a (cante / coma). That is a case of reciprocal paradigm structure conditions (Present Indicative vs. Present Subjunctive. With thematic vowel $a$ vs. subjunctive $e$ and viceversa)

Microclassses are mostly formed by alterations in the root. There are only some cases of alterations in suffixes in the case of verbs like dar, estar ( $1^{\text {st }}$ per. sg. doy, estoy), in the strong perfects (anduvo, supo) and participle (hecho, abierto) and in the short imperatives (sal, ven, $d i$ instead of sale, vene, dice)

Spanish verbal morphology is highly iconic, firstly because the most frequent and semantically least marked categories are featureless encoded (present, $3^{\text {rd }}$ per. sg and imperative) and secondly because suffixes are nearly the only markers.

There is almost no syncretism and almost no homophony.

Only 3 p. s. pres. ind. and 2 p. imperative are homophonous.

There is syncretism in the 1-3 per. sg. in pretérito imperfecto de indicativo, presente de subjuntivo, pretérito imperfecto de subjuntivo, futuro imperfecto de subjuntivo and conditional.

\subsection{Paradigm models - present of indicative for the three classes}

\begin{tabular}{|c|c|c|c|}
\hline & to sing & $2^{\text {nd }}$ temer to be afraid & $3^{\text {rd }}$ partir 'to leave' \\
\hline $\mathrm{Sg}$ & canto & temo & parto \\
\hline & cantas & temes & partes \\
\hline & canta & teme & parte \\
\hline $\mathrm{Pl}$ & cantamos & tememos & partimos \\
\hline & cantáis & teméis & partís \\
\hline & cantan & temen & parten \\
\hline
\end{tabular}

\subsection{Subregular and irregular verbs used by the child in this period:}

Caer 'fall': caigo, caes, cae, caemos caéis, caen.

Traer 'bring': traigo, traes, trae, traemos, traéis, traen.

Dormir 'sleep': duermo, duermes, duerme, dormimos, dormís, duermen.

Venir 'come': vengo, vienes, viene, venimos, venís, vienen.

Poner 'put': pongo, pones, pone, ponemos, ponéis, ponen.

Tener 'have': tengo, tienes, tiene, tenemos, tenéis, tienen.

Hacer'do': hago, haces, hace, hacemos, hacéis, hacen.

Estar 'be': estoy, estás, está, estamos, estáis, están.

Querer 'want': quiero, quieres, quiere, queremos queréis, quieren

Poder 'can ': puedo, puedes, puede, podemos, podéis, pueden.

\subsection{Suppletives}

Ser: soy, eres, es, somos, sois, son.

Ir: voy, vas, va, vamos, vais, van.

1.8. Auxiliar haber (have, used in the analytic past perfect)

He, has, ha, hemos, habéis, han. 


\section{Data base}

This study is based on longitudinal spontaneous speech data of one Spanish boy, Magín ${ }^{3}$. This boy is the third and last child of a couple living in Madrid. The mother, who was the researcher, recorded him regularly in everyday situations. Data collection started when Magín was 19 months old $(1 ; 7)$, just in the moment when he was beginning to build up two-word utterances and it finished at $31(2 ; 7)$ months. The total amount of data is 28 recorded hours with 3766 utterances.

\section{Magín's verb production}

\subsection{Emergence of verb forms}

Before the first tape was recorded, at 1;7, there are some diary notations that show the first words acquired by Magín in the one word-stage. At this moment he uses only a few words, and some of them are verbs. At 1;4 he employs ma for quema (it burns) in any danger situation or apapa, for apaga (switch of, imperative), when he wants to switch on or switch off the light. One month later, at 1;5, he begins to use the imperative abre (open) and a formulaic utterance be abá instead of quiero beber agua (I want to drink water). This is a context bound expression, because he employs it exclusively when he wants to drink water (agua). He seems to have amalgamate, with agua, the verb beber that he has truncated in be, and it can have been taken from the frequent adult question addressed to the child: iquieres beber agua? (do you want to drink water?). At 1;6 he employs quere and quero ( 3 and 1 per. sg., respectively of want) and quita (keep away, imperative).

\subsection{Quantitative data of verb production}

Table 1: Number of verb lemmas, types and tokens from 1;7 to 1;10 (without repetitions and frozen forms. Percentages with respect to the number of analysed utterances ${ }^{4}$ )

\begin{tabular}{|c|c|c|c|c|c|c|c|}
\hline Age & Lemmas & Types & $\begin{array}{c}\text { Incorr } \\
\text { types }\end{array}$ & Tokens & $\begin{array}{c}\text { Incorr } \\
\text { tokens }\end{array}$ & tokens \% & $\begin{array}{c}\text { Analysed } \\
\text { utt. }\end{array}$ \\
\hline $1 ; 7$ & 8 & 10 & $2^{5}$ & 19 & 3 & $50,0 \%$ & 38 \\
\hline $1 ; 8$ & 15 & 17 & 1 & 33 & 2 & $29,4 \%$ & 112 \\
\hline $1 ; 9$ & 24 & 32 & & 78 & & $32,6 \%$ & 239 \\
\hline $1 ; 10$ & 45 & 65 & & 190 & & $42,4 \%$ & 448 \\
\hline
\end{tabular}

The incorrect types and tokens are forms that do not belong to the target language.

As we can see in the table above, Magín is a child that uses a lot of verbs from the very beginning. As he enters the two-word stage at 1;7, we find that almost $50 \%$ of the utterances produced are utterances that contain a verb. A lot of them contain just one verb. At this moment his MLU is only 1.43 and most of the expressions are one-word utterances (23 from a total amount of 38). The data show that 14 of them are integrated for just a verb while only 9 are formed by a noun or by a determinant.

\footnotetext{
The data presented in this study are included in Aguirre's PhD thesis (Aguirre 1995).

4 To qualify as an utterance, a production has to include at least one meaningful unit resembling a Spanish word in form and meaning. Babbling, vocalizations and completely incomprchensible strings werc not considered utterances. Citations (e.g. nursery thymes and songs) and direct imitations were excluded from the analysis.

5 He uses the formulaic form a mir, instead of the adult form a dormir and the incorrect form caye instead of cae.
} 


\subsection{Verb categories before protomorphology}

This stage lasts until Magín is 1;10, the moment when the first three-member miniparadigms begin to appear. Nevertheless we assume that at 1;9 the child is in a transition phase in which some two-member paradigms are produced.

The quantitative data in table 3 showed that predication is essential in Magín's first verbal communication and he does not have any problem in acquiring verbs to make these predications. This characteristic of Magín's early acquisition explains why we do not find precursors of verbs made with onomatopoeic elements or with nouns.

The first two-word combinations, at 1;7, mark the beginning of Magin's development of syntax. At that moment we find 6 predication structures with clear thematic relations among them. All of them contain a verb:

Verb + Object:

(1) Quiero aba. 'I want water'

(2) Be abá. 'drink water'

(3) Trae a bobo. 'bring the balloon'

Subject + Verb:

(4) Eto pincha. 'that pricks'

(5) Mamá cae. 'mum fall down'

(6) Pipi no tan. 'bird are not'

Predication structures increase with every recording and the sentence development that goes with it can easily explain the apparently strange decrease in the use of verbs that we find in the data (from $50 \%$ utterances with verb at $1 ; 7$ to $29 \%$ at $1 ; 8$ ).

The development of syntax that begins with these first two-word utterances may cause a paradoxical phenomenon. To a child, like Magín, who uses a big quantity of verbs in his one word stage it might happen that limitations in processing capacity make it very difficult to form utterances with more than two words. This leads the child to omit the verb when two other elements take part in the thematic relations. That is the case with some two-word structures at 1;8:

Locative:

(7) Estrella, allí. 'Star there'

(8) Estrella arriba. 'Star up'

(9) Ahi a pelota. 'There the ball'

Object:

(10) Mi polota. 'My ball

Subject + Object:

(11) Magín caca. 'Magín shit'

Complex thematic structure:

(12) Lo papapo, pobrecito. "The shoes, poor'. He wants to say something like: "poor daddy, I have hit him with the shoe".

A similar verb omission happens when a vocative element occurs in the utterance ${ }^{6}$ :

(13) Mamá, mi tatín. 'Mum, my sock'

(14) Mamá, a bolsa. 'Mum, the bag'

6 The same kind of omission is possible in adult standard Spanish. 
At this stage the word combinations and the context adequacy indicate that he knows about the meaning of the verbs. At the same time, the syntax begins to develop and the child may use the small set of verbs he has in his repertory in thematic relations with the appropriate nouns in the appropriate context. The following examples show some multi- word utterances where the verb appears in thematic relations with some nominal phrases:

Verb + Object:

(15) Echa, echa tatón. 'Throw, throw stopper'

(16) Po papapo pono. 'The shoes I put'

Verb +Object + Locative:

(17) Quiero agua tatita. 'I want water small cup'

(18) Tatita, bebe aba. 'Small cup, drink water'

Subject + Verb:

(19) La araña te viene. 'The spider that comes'

The child seems to know that quiero (I want), or pono (I put) are expressions of desire and that they have to cooccur with the word denoting the desired thing.

\subsubsection{Development of morphology:}

At this stage, at 1;7, Magín uses infinitives such us:

A mir (instead of the adult form a dormir), to sleep' (in imperative tone) and abrir 'to open` (in imperative tone).

Imperatives such us:

Abre 'open' and quita 'take away'.

Third singular present forms such us:

Quema 'it burns`, cae (Mama cae. 'It falls down, mum') and pincha 'it pricks`.

Magín also uses first singular present forms such us:

Quiero (quiero aba.'I want water'), quito (quito tatín, with imperative meaning, 'I take off the sock') and pongo (Mamá, a pongo. -With imperative meaning- 'Mamí, I put it.')

At $1 ; 8$, we also find two verbs used in the third person plural present form?

No tan, instead of the adult form no están, (no tan e pipi. 'Are not the bird'), and Be van, instead of the adult form se van (be van, avión. 'Leave, the plain'). These two forms are used to express non-existence.

Although different verbal forms have been used, morphological rules are not operative at this stage and the verbal forms produced are rote learned. In the same way, no functional categories linked to the verb (tense, mood, aspect, person and number) are present at that moment. Consequently most of the verbs are used in only one form and this gives rise to a lot of agreement errors. The rate of agreement errors is situated between $40 \%$ and $50 \%$ at $1 ; 7$ and $1 ; 8$ months old.

7 All these occurrences of third person plural are agreement errors. The subject appears al ways in the singular. At that moment the child is not able to use the plural in nouns. 
Figure 1. Magín: Development of agreement errors.

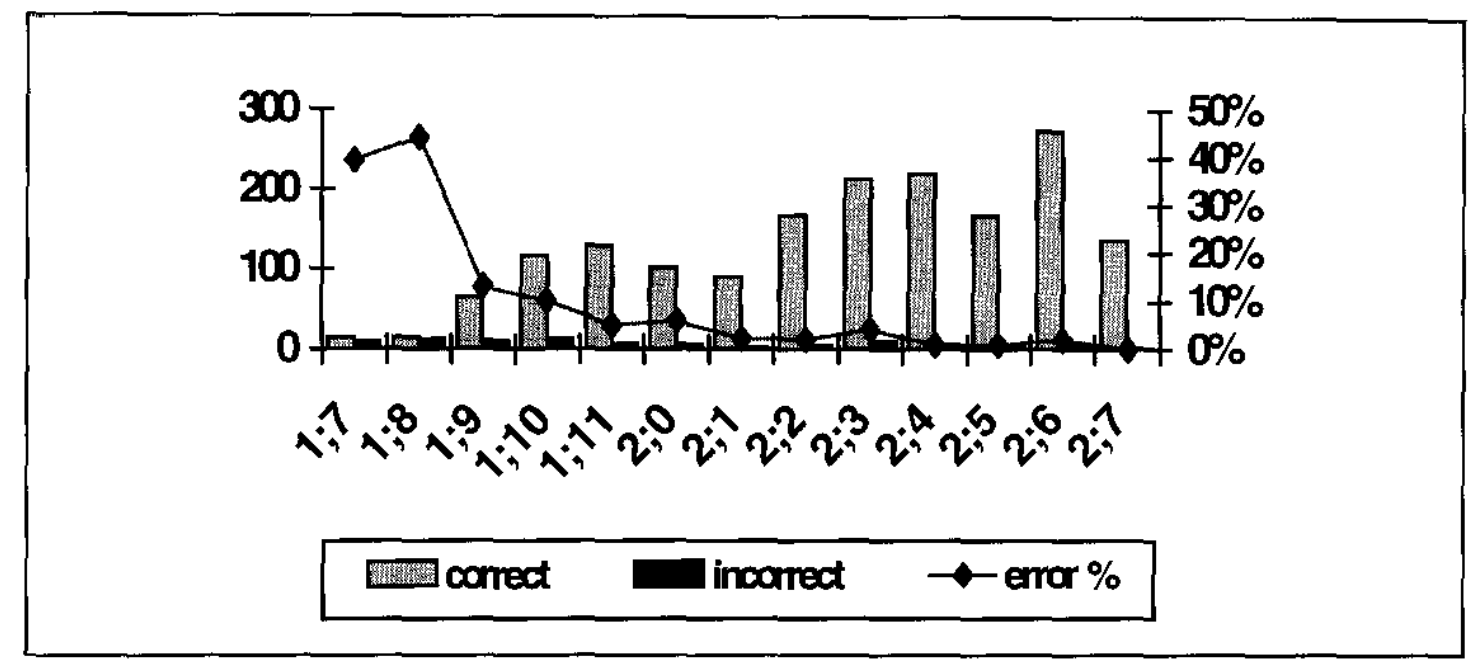

Some of these errors are produced in question-answer structures, where it is easy to see that the child is not able to change the person that he has heard in the question in order to arrive at the correct form in the answer:

(20) a - Mother: - ¿Te lo abro? 'Shall I open it?'

Child: - Abro. 'I open'

b - Mother: - ¿Que lo eche? 'Shall I throw (3 per. sg. subj.)it?'

Child: - Eche. "Throw (3 per. sg. subj.)'

We can see this absence of productivity in the use of the verb forms in the difference between lemmas and types presented in table 1 . At 1;7 the number of verb lemmas used by the child is 8 while the number of verb types is 10 . The same difference is found at $1 ; 8$ where we find 15 verb lemmas and 17 verb types. In both cases the only verb that appears in more than one form is the verb abrir; all the rest of the verbs (up to 25 documented in this period) are fixed to only one form.

Magín sometimes appears to have stored just the most frequent input form; for instance, he uses the verb dormir (sleep) in the infinitive because his mother says often a dormir when she wants the baby to go to sleep. In some cases the child may pick up by chance some less frequent form and overgeneralize its usage. This is the case with the $3^{\text {rd }}$ person plural no tan (no están 'they are not'), a frozen form that he uses to express non-existence. He has picked up this verbal form while looking at, and playing with, a drawing book together with his mother. This book was especially designed for learning the numbers, so it had many balloons, dolls, etc.

Most of the verbs used in this period are produced in present tense. But we also find, at $1 ; 8$, a change-of-state verb in past perfect form. This verb, asustar (frighten), is only produced in this perfect form, the auxiliary is occasionally absent, and it is always used in the third person singular:

Past perfect. (Aux. + Part.)

(21) a - Ha tutado. 'It has frightened'

Participle (adjectival use).

(22) a - Avión tutado. 'Plain (has) frightened (me)'

b - Tutado, tutado, abé. '(Has) frightened, frightened (me), abe' 
This lack of productivity leads us to conclude that these verbal forms are still unanalyzed in this initial stage and the kind of predication that they involve is very close to adjectival predication.

3.3.2. Emergence of miniparadigms. Pre-paradigm step (cf. Kilani-Schoch \& Dressler 2000)

Magín's use of verb types of the same lemma (without repetitions and frozen forms):

$1 ; 7^{8}$ : Abrir, open: imperative abre; pres subj. $3^{\text {rd }}$ per. sg. abra ${ }^{*^{9}}$; infinitive abrir*.

1;8: Abrir, open: infinitive abrir; imperative abre; pres ind. $3^{\text {rd }}$ per. sg. abre*.

As we can see, the verb abrir is the only one that appears in different verb forms. Judged from the adult targets, it appears with a lot of agreement mistakes. This shows that the child is only aware of the fact that some words have different endings. Accordingly, we find a very interesting sequence of words in the first recording session, in which Magín wants his mother to open a bag, but she does not open it. The child gets increasingly anxious and, instead of repeating the imperative form abre (also $3^{\text {rd }}$ per. sg. indicative present) he tries to get his

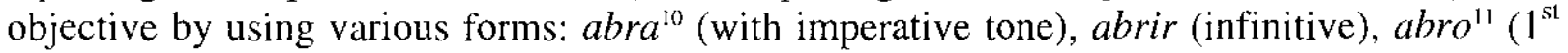
per. sg. indicative present).

We claim that all these different forms are rote-learnt and, therefore, part of the lexicon. Magín does not identify the suffixes as morphological elements that codify semantically and syntactically distinct categories linked to the verb (person, tense, mood...). The use of these endings in verbal forms does not reveal any procedure based on processing, that is, any procedure in which the child is applying any formation rule. So, these different ending forms are not productive, yet. In this sense we cannot consider this case as a real miniparadigm. The fact that most of the verbs are used in only one grammatical person and one single tense, together with the high level of agreement errors produced and the still poor development of syntax leads us to conclude that these different verbal suffixes are yet unanalysed.

\subsubsection{Transition phase}

The end of the premorphological period $(1 ; 9)$ can be considered as transition towards the protomorphological stage, because some two member paradigms develop but not enough morphological alternation is yet available for compelling the child to engage in morphological analysis.

Magín's use of verb types of the same lemma (without repetitions and frozen forms) at 1;9:

6 two-member mini-paradigms:

Class 1:

Pinchar (prick): pres ind. $3^{\text {rd }}$ per. sg. pincha: pres ind. $3^{\text {rd }}$ per. pl. pinchan.

Class 2 (er):

Romper (breake): pres ind. $3^{\text {rd }}$ per. sg. rompe; past perfect ind. $3^{\text {rd }}$ per. sg. se ha roto.

\footnotetext{
I have not considered the frozen forms no tan and se van that Magín uses to express non existence. Most of them are used incorrectly in plural instead of singular.

9 The asterisk means that there is an agreement error.

10 In this case it is possible that the child is adding, erroneously the thematic vowel $a$ from the first conjugation, instead of using the appropriate thematic vowel $e$, but it is also possible that he is selecting the ending of negative imperative, the form of subjunctive no abras.

11 This is a repetition. The mother has just said it before.
} 
Caer (fall): pres ind. $3^{\text {rd }}$ per. sg. cae; pretérito indefinido (past perfect ind. synthetic form) $3^{\text {rd }}$ per. sg. cayó.

Querer (want): pres. ind. $3^{\text {rd }}$ per. sg. quiere ${ }^{*}$, pres. ind. $1^{\text {st }}$ per. sg. quiero.

Class 3 :

Abrir (open): infinitive abrir; imperative abre.

Suppl.

Ir (go): pres ind. $3^{\text {rd }}$ per. sg..se va; past perfect ind. $3^{\text {rd }}$ per. sg. se ha ido.

At this stage, there is no evidence that the child is analysing any agreement marker in the opposition of person and number forms (pincha / pinchan and quiere / quiero). In the case of pincha / pinchan, both forms appear in the same situation. He used pincha (one word utterance), referring to a place where there are some branches that prick, except in one case where he said pinchan. In the case of quiere / quiero, the first one is an agreement mistake because he is referring to himself.

About the use of different forms with present / past (perfect) ${ }^{12}$ opposition, we think that the child is matching the past-perfect forms with the past-perfect meaning, thus showing contrastive use in adequate contexts.

In the following examples, all produced at $1 ; 9$, we can see how the past perfect forms (in bold) alternate with present forms, of the same verb, appropriate to the context.

(23) a. La nuna se ha roto. Mira se ha roto. Rompe, rompe.

'The moon is broken. Look, it's broken. Breaks'

b. Cayó. 'It fell down'

c. ¡Ay! Que se cae. 'Ouch! That it fall down` (just before falling down).

The examples with the verb $i r$ (go) are more problematic because Magin alternates the pastperfect form se ha ido with the presents se va, no tan and no ta in order to express nonexistence.

(24) a. Roni no tan. Se ha ido. 'Roni is not here. He is gone.'

b. Se va cacón. 'Snail leaves'

A more problematic question is to find out whether the child has begun to analyse the suffixes as separate elements of the verb, as exponents of syntactic categories that encode a new meaning. Our proposal is that at this step, the child learns different forms of a given verb and links them to different meanings associated with the verb (as we have seen, mainly tense at the beginning); but the child has not yet discovered that the affix is the element that conveys such meanings. In other words, he has not discovered the affix and the verb is still contemplated as a whole.

Two main reasons lead us to this conclusion. The first one is quantitative. At this stage the child has still too few examples of different verb forms for one single verb, and a sufficient amount of elements is needed for developing morphology. The second reason is qualitative. As we have seen, the person distinctions do not show that the child is really marking the subject with these different forms. In the case of tense distinctions, the child uses the contextually appropriate form. However, from the three examples that we find, one is made with the suppletive verb $i r$, another one with the strong participle roto that will be regularized later on in the data (rompido), and the last one belongs to a kind of past (pretérito indefinido, synthetic past perfect) that is not much used in oral speech in the Madrid area and will appear productively only late in the acquisition process.

12 I do not go here into the problem of aspect before tense acquisition or viceversa. 
In this sense we prefer considering this period as a transitional one.

\subsection{The protomorphological stage}

At this stage, the child begins to go beyond the verb meaning, as he seems to develop sentences syntactically, acquiring the functional categories Agreement and Tense.

For the first time, we find evidence that Magín is beginning to analyse the verbal suffixes as verb elements that convey information about tense and person (subject of the predication). This discovery is triggered by the lexical acquisition of the first different verb forms and, once it is produced, it also triggers the quick acquisition of the agreement morphology of Spanish and, thus, starts protomorphology with the emergence of the first miniparadigms ${ }^{13}$.

\subsubsection{Emergence of miniparadigms}

Magín's use of verb types of the same lemma (without repetitions and frozen forms) at 1;10:

1 four-member mini-paradigm:

Suppletive.

Ir (go): pres ind. $3^{\text {rd }}$ per. sg..va ; pres ind. $3^{\text {rd }}$ per. pl. van*; pres ind. $1^{\text {st }}$ per. pl. vamos; past perfect ind. $3^{\text {rd }}$ per. sg. se ha ido.

2 three-member mini-paradigm:

Class 2 (er):

Hacer (do): pres ind. $3^{\text {rd }}$ per. sg. hace; pres subj. $3^{\text {rd }}$ per. sg. no haga*; pres subj. $2^{\text {nd }}$ per. sg. no hagas.

Abrir (open): infinitive abrir; imperative abre, pres ind. $1^{\text {st }}$ per. sg. abro.

11 two-member paradigms:

Class 1:

Duchar (shower): infinitive a duchar; gerund (present continous) pres ind. $3^{\text {rd }}$ per. sg se está duchando.

Quitar (take off): imperative quita, pres ind. ${ }^{\text {st }}$ per. sg. quito*.

Asustar (frighten): pres ind. $3^{\text {rd }}$ per. sg asusta, pres subj. $2^{\text {nd }}$ per. sg. no asustes.

Mojar (wet): pres ind. $3^{\text {rd }}$ per. sg moja, bare past participle mojado (adjectival use).

Class 2 (er):

$\operatorname{Ver}$ (see): infinitive ver; pres ind. $1^{\text {st }}$ per. sg. veo

Coger (take): pres ind. $1^{\text {st }}$ per. sg. cojo; gerund cogiendo.

Querer, (want): pres ind. $3^{\text {rd }}$ per. sg. quiere (quere); pres ind. $1^{\text {st }}$ per. sg quiero (tero).

Poner, (put): pres ind. $1^{\text {st }}$ per. sg. pongo (pono), imperative pon (pon, pone)

Class 3 (ir):

Venir, come: imperative ven, pres ind. $3^{\text {rd }}$ per. sg.viene.

Suppl.

Ser (to be): pres ind. $3^{\text {rd }}$ per. sg es; pres ind. $3^{\text {rd }}$ per. pl son.

1.3 A similar proposal has been developed in syntax to explain the acquisition of functional categories: the Lexical Lcarning Hypothesis (Clahsen \& Penke 1992, Meisel \& Müller 1992). Under this assumption, it is only when the child learns the lexical elements that new projections are added to existing phrase-structure representations. Clahsen, Eisenbeiss \& Penke 1996 defend a "Morphological Bootstrapping". Their idea is that functional categories such as IP, AGRP, etc or syntactic features may come into the child's phrase structure as a consequence of the child's learning a regular inflectional paradigm. 
Modal.

Poder (can): pres ind. $3^{\text {rd }}$ per. sg puede*; pres ind. $1^{\text {st }}$ per. sg puedo.

Table 2: Emergence of miniparadigms

\begin{tabular}{|l|l|l|l|l|l|}
\hline Age & $\begin{array}{l}\text { True } \\
\text { mini- } \\
\text { paradigms }\end{array}$ & $\begin{array}{l}2 \text { members } \\
\text { mini- } \\
\text { paradigms }\end{array}$ & $\begin{array}{l}\text { Mini- } \\
\text { paradigms } \\
\text { per month }\end{array}$ & $\begin{array}{l}\text { Paradigm } \\
\text { values } \\
\mathrm{P}(\mathrm{utt})\end{array}$ & $\begin{array}{l}\text { Paradigm } \\
\text { values } \\
\mathrm{P}(\mathrm{lem})\end{array}$ \\
\hline $1 ; 7$ & - & - & - & $0 \%$ & $0 \%$ \\
\hline $1 ; 8$ & - & - & - & $0 \%$ & $0 \%$ \\
\hline $1 ; 9$ & - & 6 & 6 & $2,5 \%$ & $25 \%$ \\
\hline $1 ; 10$ & 3 & 11 & 14 & $3,1 \%$ & $31,1 \%$ \\
\hline
\end{tabular}

Since the number of mini-paradigms attested in one corpus depends on sample size, we propose two sample-size independent values for investigating the development of the paradigm formation capacity in a child. The first value, $P$ (utt), is calculated by dividing the number of mini-paradigms by the number of analysed utterances per month. The second value, $\mathrm{P}$ (lem), which serves as an index for the paradigm formation capacity of the child in relation to his verb lexicon: it is calculated by dividing the number of mini-paradigms by the number of verb lemmas per month. The paradigm values $\mathrm{P}(\mathrm{utt})$ and $\mathrm{P}(\mathrm{lem})$ are supposed to provide an objective base for the comparison of mini-paradigms across corpora and languages (see also Klampfer and Katičic this volume).

Our data show a real spurt in the miniparadigms emergence. At 1;9 we still do not find any true mini-paradigms ( 3 member miniparadigm, following Kilani-Schoch \& Dressler 2000 criteria), there are only 6 verbs used in two different forms (see 3.3.2); but one month later, at $1 ; 10$, Magín has already built 3 true miniparadigms and 11 two-member paradigms.

Table 3: Emergence of verb categories (number of tokens)

\begin{tabular}{|l|l|l|l|l|l|l|l|l|l|}
\hline Age & $\begin{array}{l}\text { Pres. } \\
\text { indic. }\end{array}$ & Impera. & Infinit. & Partic. & Gerund & $\begin{array}{l}\text { Synthet } \\
\text { Past } \\
\text { perfect }\end{array}$ & $\begin{array}{l}\text { Analyt. } \\
\text { Past } \\
\text { perfect }\end{array}$ & $\begin{array}{l}\text { Present } \\
\text { Subjun }\end{array}$ & $\begin{array}{l}\text { Present } \\
\text { Contin. }\end{array}$ \\
\hline $1 ; 7$ & 4 & 4 & 3 & & & & & 1 & \\
\hline $1 ; 8$ & 7 & 5 & 4 & 1 & & & & & \\
\hline $1 ; 9$ & 41 & 3 & 5 & 13 & & 2 & 8 & 1 & \\
\hline $1 ; 10$ & 123 & 38 & 13 & 6 & 2 & & 5 & 3 & 1 \\
\hline
\end{tabular}

\subsubsection{Tense-aspect and agreement distinction in the same verb lemma}

Looking at these first miniparadigms we can observe that there is not just one pattern. Regarding morphology acquisition, the child seems to be acquiring tense-aspect and agreement distinction at the same time, as well as some other distinction that does not fit these two main groups, e.g. infinitive - present, imperative - present or indicative subjunctive (only for prohibitive at this stage).

\section{Tense-aspect distinction:}

Present / past-perfect.

$\operatorname{Ir}$ (go): $\quad$ pres ind. $3^{\text {rd }}$ per. sg. $v a$ Romper (break): pres ind. $3^{\text {rd }}$ per. sg. rompe Caer (fall): $\quad$ pres ind. $3^{\text {rd }}$ per. sg. cae
- past perfect ind. $3^{\text {rd }}$ per. sg. se ha ido.

- past perfect ind. $3^{\text {rd }}$ per. sg. se ha roto.

- pretérito indefinido (past perfect ind. synthetic form) $3^{\text {rd }}$ per. sg. cayó. 
Present or infinitive / Gerund (continuous present)

Duchar (shower): infinitive a duchar

Coger (take): $\quad$ pres ind. $1^{\text {st }}$ per. sg. cojo
- gerund (present continous) pres ind. $3^{\text {rd }}$ per. sg se está duchando.

- gerund cogiendo.

\section{Agreement distinction:}

$3^{\text {rd }}$ person singular $-3^{\text {rd }}$ person plural

$\operatorname{Ir}$ (go): $\quad$ pres ind. $3^{\text {rd }}$ per. sg. $v a$

Pinchar (prick): pres ind. $3^{\text {rd }}$ per. sg. pincha

Ser (to be): $\quad$ pres ind. $3^{\text {rd }}$ per. sg es

$1^{\text {st }}-3^{\text {rd }}$ person singular

Querer (want): $\quad$ pres ind. $3^{\text {rd }}$ per. sg quiere

Poder (can): $\quad$ pres ind. $3^{\text {rd }}$ per. sg puede*

$3^{\text {rd }-2^{\text {nd }}}$ person singular

Asustar (frighten): pres ind. $3^{\text {rd }}$ per. sg asusta
- pres ind. $3^{\text {rd }}$ per. pl. van*

- $\quad$ pres ind. $3^{\text {rd }}$ per. pl. pinchan.

- pres ind. $3^{\text {rd }}$ per. pl son.

- pres ind. $1^{\text {st }}$ per. sg quiero.

- pres ind. $1^{\text {st }}$ per. sg puedo.

- $\quad$ pres subj. $2^{\text {nd }}$ per. sg. no asustes.

Table 4: Development in the use of grammatical persons

\begin{tabular}{|c|c|c|c|c|c|c|c|c|c|c|c|c|c|}
\hline & & \multicolumn{5}{|c|}{ Present forms (tokens) } & \multicolumn{5}{c|}{ Past forms (tokens) } \\
\hline & & \multicolumn{3}{|c|}{ Singular } & \multicolumn{3}{c|}{ Plural } & \multicolumn{3}{c|}{ Singular } & \multicolumn{3}{|c|}{ Plural } \\
\hline Months & Utterances & $1^{\text {st }}$ & $2^{\text {nd }}$ & $3^{\text {rd }}$ & $1^{\text {st }}$ & $2^{\text {nd }}$ & $3^{\text {rd }}$ & $1^{\text {st }}$ & $2^{\text {nd }}$ & $3^{\text {rd }}$ & $1^{\text {st }}$ & $2^{\text {nd }}$ & $3^{\text {rd }}$ \\
\hline $1 ; 7$ & 38 & 1 & & 3 & & & & & & & & & \\
\hline $1 ; 8$ & 112 & 1 & & 6 & & & & & & & & & \\
\hline $1 ; 9$ & 239 & 10 & & 29 & 1 & & 1 & & & 10 & & & \\
\hline $1 ; 10$ & 448 & 13 & & 89 & 6 & & 15 & & & 5 & & & \\
\hline
\end{tabular}

Repetitions and frozen forms have been excluded from the analysis.

The development of miniparadigms is the strongest argument in support of the claim that the child is entering the protomorphological stage. But another argument that supports this claim has to do with mistakes concerning the development of agreement. During this period the child begins to use the verbal forms properly and the rate of errors decreases rapidly in this period (see figure 1).

This stage $(1 ; 10)$ is also very important for the acquisition of verb vocabulary. The increase in the number of verbs used is dramatic. The number of verbs (lemmas) in Magín's vocabulary is only about 19 when he is $1 ; 7$ months old, 23 at 1;8 months, 32 at 1;9 months and it reaches 60 when he is $1 ; 10$ months old ${ }^{14}$. In this sense, we can say that a verb spurt takes place at this stage. The MLU, in which we can see the syntactic development, increases in the same striking way, from 1.89 when he is $1 ; 9.1$ to 2.5 when he is $1 ; 11$. So, we can conclude that this moment of identification of functional categories, when verb morphology starts to develop and the child enters the protomorphological stage, is also a key moment in the acquisition of verbs (specially verb vocabulary) and syntax.

\subsection{Inflectional classes}

As we can see in the table below there is not a preference for the first macroclass in the first verbs acquired by the child. During the premorphological stage, there is a predominance of verbs from the er class. This fact is not striking: there may be few verbs in the second macroclass, but some of them are among the most frequent in Spanish. At this stage the verb

14 Although the number of analysed utterances is much higher in the last recordings there are some diary notations that show that Magin's verb vocabulary is not higher during the time of the first recordings. 
is only a lexical element and the class system has not begun to develop, thus token frequency is of paramount importance.

At the protomorphological stage, the tendency is reversed and most of the new verbs learned belong to the first macroclass. This fact leads us to think, that once class formation has started, the verbs belonging to the first macroclass are easier to acquire.

Table 5: Distribution of verb lemmas / types / tokens with regard to inflectional classes.

\begin{tabular}{|c|c|c|c|c|c|c|c|}
\hline Age & Class 1 & Class 2 (er) & $\begin{array}{c}\text { Class 2 } \\
\text { (ir) }\end{array}$ & Suppl. & Auxiliars & Modals & Total \\
\hline $1 ; 7$ & $3 / 3 / 6$ & $3 / 3 / 4$ & $2 / 4 / 9$ & & & & $8 / 10 / 19$ \\
\hline $1 ; 8$ & $5 / 5 / 13$ & $7 / 7 / 12$ & $3 / 5 / 8$ & $1 / 1 / 2$ & $1 / 1 / 2$ & & $15 / 17 / 33$ \\
\hline $1 ; 9$ & $10 / 10 / 35$ & $11 / 15 / 31$ & $3 / 6 / 12$ & $2 / 3 / 6$ & $1 / 1 / 8$ & $1 / 1 / 1$ & $24 / 32 / 78$ \\
\hline $1 ; 10$ & $28 / 34 / 86$ & $11 / 20 / 55$ & $6 / 12 / 49$ & $2 / 5 / 37$ & $2 / 2 / 6$ & $1 / 2 / 2$ & $45 / 66 / 190$ \\
\hline
\end{tabular}

\section{Conclusions}

The acquisition of the Spanish verb, in Magín, shows two main stages:

A premorphological one that lasts till $1 ; 9$ and a protomorphological one that begins at $1 ; 10$. At the premorphological stage the verbs are learned as not-decomposable lexical elements. At $1 ; 7$ they begin to be the main component in predication structures in which thematic relations are involved. At 1;10, the child enters the protomorphological stage and the verb suffixes begin to be analysed as separate elements. At that moment the morphological component starts to develop and the first miniparadigms emerge.

\subsection{Premorphological stage}

In this period, when the child uses verbs, he pays attention only to their lexical meaning.

The child uses an inflected form, but this form is still unanalyzed. That means that it is rotelearnt. The only category present is the verb itself, other categories linked to the verb (tense, person, $\operatorname{mood} . .$.$) are still absent.$

If the child does not analyze the end of the verb as a suffix at all, we cannot make any predictions about the acquisition of verbal morphology. This is because the acquisition of verbal morphology is not taking place at this moment.

This main assumption helps us to explain why Magín normally has, at this first period, only one form for every verb. An economical consideration (perhaps also naturalness considerations), one form - one meaning, predicts that the tendency will be that the child will choose one form and only one for every verb (normally context-bound, in the first uses). Therefore different verbal forms of the same verb will not be normal and if they appear they will be context-bound or incorrect forms, as we have seen in our data.

An interesting problem appears when we want to explain why one form from the repertory rather than another is chosen by the child. In this respect, Magín's data leads us to claim that the chosen form is taken because:

a) it is the most frequent form for a particular verb in child speech;

b) it is the form "captured" by the child in a given context, and after that he fixes it;

c) it is perceptually the most salient form for a particular child

The first consideration, $a$, predicts that we will find a wide diversity of verb-forms in verbvocabulary. This assertion is corroborated by Magín's data (dormir, quita, pongo...). We also 
expect that a language with rich verbal inflection, like Spanish, will show more diversity of forms in verb vocabulary at this first step than languages with poor inflection. In case of homophony, we also expect that homophonous forms are bound to appear more often than non-homophonous ones. That is the case with Magín's data in which the $3^{\text {rd }}$ person singular, homophonous with the $2^{\text {nd }}$ person singular of imperative is clearly the most frequently used form.

The second point, $b$, predicts that we will find differences between the children that acquire the same language. We have taken into consideration the data of only one child, but we find some strange verb forms used, like the already commented $3^{\text {rd }}$ person plural of verb estar, that should not be expected in other children.

The last consideration, $c$, predicts that we will find differences between languages, (e.g. $3^{\text {rd }}$ per sg can be very salient in Spanish phonological system because it is a disyllabic word finishing by an overt vowel, but not very salient in German because it finishes in an occlusive consonant $t$ ).

In summary, this period should generally be characterized by diversity among acquisition processes of different languages as well as diversity among children learning the same language.

\subsection{Protomorphological stage}

In this period the verbal suffixes begin to be analyzed and the construction of paradigms is gradually developed.

We hold that the entrance in this stage will be triggered and guided by the morphological characteristics of the language the child is exposed to and, hence, naturalness considerations and typological constraints may predict the acquisition process of verb morphology across languages.

The high degree of naturaIness witnessed in Spanish verbal inflection leads us to predict that the protomorphological stage will begin early in its acquisition process and neither the number of errors in the same process nor the number of overgeneralizations will be very high. This prediction is corroborated by our data where the protomorphological stage develops early on, the number of errors is minimal, and overgeneralizations are sparse and occur relatively late.

Naturalness considerations acquisition paths will start with the most unmarked forms. Spanish shows a verbal form not marked at all: the $3^{\text {rd }}$ per. sg. of indicative present (the same form also symbolizes, nearly always, the $2^{\text {nd }} \mathrm{sg}$ imperative form, another morphosemantically unmarked category).

This form is morphosemantically and morphotactically unmarked. The indicative present lacks suffix 1 (tense, mood and aspect suffix) as well as suffix 2 (agreement suffix). Therefore we should expect that this form will be the first one to appear. This prediction, in fact, is borne out in our data. If we examine Magín's development of miniparadigms, we can see than in almost all of them one of the components is the $3^{\text {rd }}$ per. sg. of indicative present. 


\section{References}

Aguirre, C. (1995): La Adquisición de las Categorías Gramaticales en Español. Tesis doctoral. Universidad Autónoma de Madrid.

Clahsen, H. / Penke, M. (1992): The acquisition of agreement Morphology and its syntactic consequences: new evidence on german child language from the Simone-corpus. In: Jürgen M. Meisel (eds). The Acquisition of Verb Placement. Dordrecht, Kluwer Academic Publishers.

- $\quad$ / Eisenbeiss, S. / Penke, M (1996): Towards a Structure-Building Model of Acquisition. In H. Clahsen (Eds.), Generative perspectives on language acquisition: Empirical findings, theoretical considerations, crosslinguistic comparisons. Amsterdam: Benjamins.

Dressler, W.U. (ed.) (1987): Dressler, W. U.; W. Mayerthaler; O.Panagl \& W. U. Wurzel, Leitmotifs in Natural Morphology. Amsterdam: Benjamins.

Kilani-Schoch, M. (1988): Introduction à la morphologie naturelle. Berne. Reidel.

- / W. U. Dressler (2000): The emergence of verb paradigms in two French corpora as an illustration of general problems of pre- and protomorphology. Poster presented at the $9^{\text {th }}$ Int. Morphology Meeting, February 2000.

Meisel, J. \& N. Müller (1992): Finiteness and verb placement in early child grammars. In: Jürgen M. Meisel (eds). The Acquisition of Verb Placement. Dordrecht, Kluwer Academic Publishers. 
